UDC 537.876 .42

K. Savin, V. Kazmirenko, Ph.D., Yu. Prokopenko, Ph.D.

National Technical University of Ukraine "Kyiv Polytechnic Institute",

Peremogy, ave. 37, Kiev, 03056, Ukraine.

\title{
Quality Factor of Tunable Shielded Cylindrical Metal-Dielectric Reso- nator Caused by Dielectric Loss
}

The paper discusses quality factor of tunable shielded cylindrical metal-dielectric resonator taking into account dielectric losses. It was shown that dielectric loss decrease in case of the resonant frequency tuning with inclusion of the air gap between dielectric cylinder and metal plate. Calculations were performed using mode matching technique and finite integration technique. The results obtained with both methods are in good agreement. References 3, figures 2.

Keywords: metal-dielectric resonator, quality factor, dielectric loss, air gap, tuning.

\section{Introduction}

In microwave systems dielectric resonators became widely used in filters, oscillators etc. Dielectric materials make it possible to reduce dimensions of resonant elements. Shielded dielectric resonators are distinguished by their high quality factor, competitive to that of microwave cavities.

Radios of modern communication systems with dynamic channel allocation require variable filters with high quality factor maintained during tuning process.

Regular cylindrical shielded dielectric resonator usually touches the shield with its bases. It was shown, that small variable air gap between resonator's base and shield plane can serve as efficient tuning method 1. Presence of the air gap between resonator base and the shield not only allows frequency tuning, but makes influence on electromagnetic energy loss in the system.

The value of $Q$ factor of the resonator is very important for practical application. Microwave resonators which use varactors as a tunable element 2 have very good tuning range. But the $Q$ factor of such resonators decreases with a resonant frequency tuned. MEMS-based designs presented in 2 also have the similar problem: its $Q$ factor declines in case of tuning the resonant frequency.

This paper presents study of dielectric loss phenomena in tunable cylindrical shielded metaldielectric resonator. It is shown that its $Q$ factor caused by dielectric loss does not decline with an electromechanical tuning of resonant frequency.

\section{Resonator Study}

Topology of the tunable shielded cylindrical metal-dielectric resonator is presented in Fig. 1. It consists of the cylindrical-shaped dielectric of radius $R$ and height $h$ between two parallel metal plates and the shielding metal wall of radius $R_{S}$. The dielectric cylinder and the plates are coaxial. The bottom side of the cylinder is fixed to the lower plate and the upper plate is movable. There is a tunable air gap of width $d$ between the cylinder and the upper plate.

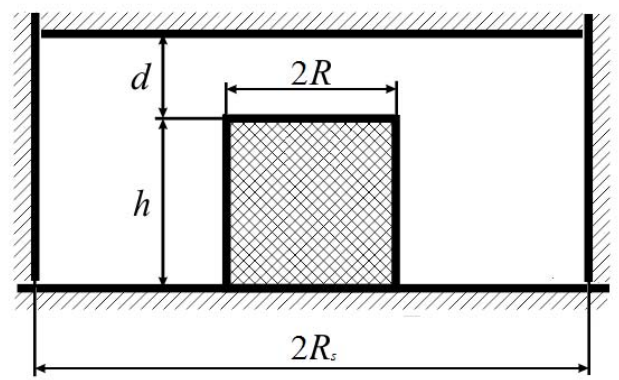

Fig. 1. Tunable shielded cylindrical metal dielectric resonator topology

\section{Analysis}

The unloaded $Q$ factor of this resonator is determined by losses of two possible mechanisms: dielectric loss and metal loss. Because of that we can describe the unloaded $Q$ factor as

$$
\frac{1}{Q_{0}}=\frac{1}{Q_{d}}+\frac{1}{Q_{m}},
$$

where $Q_{0}$ is the unloaded $Q$ factor, $Q_{d}$ is the $Q$ factor of the resonator caused by dielectric loss only (i.e. metal loss equals to zero), $Q_{m}$ is similarly the $Q$ factor caused by metal loss only.

$Q_{d}$ is defined as

$$
Q_{d}=\omega_{0} \frac{U_{d}+U_{c a v}}{P_{d}},
$$


where $U_{d}$ is the energy stored in the dielectric cylinder, $U_{c a v}$ is the energy stored in the volume of metal cavity except the dielectric cylinder, $P_{d}$ is the dissipated power in the dielectric cylinder.

$U_{d}, U_{c a v}$ and $P_{d}$ can be achieved as

$$
\begin{gathered}
U_{d}=\frac{\varepsilon \varepsilon_{0}}{2} \iiint_{\text {diel }}\left|\mathbf{E}_{2}(\mathbf{r})\right|^{2} d V \\
U_{c a v}=\frac{\varepsilon_{0}}{2}\left(\iiint_{c a V}\left|\mathbf{E}_{1}(\mathbf{r})\right|^{2} d V+\iiint_{g a p}\left|\mathbf{E}_{2}(\mathbf{r})\right|^{2} d V\right), \\
P_{d}=\frac{\omega \varepsilon \varepsilon_{0} \tan \delta}{2} \iiint_{\text {diel }}\left|\mathbf{E}_{2}(\mathbf{r})\right|^{2} d V .
\end{gathered}
$$

where $\varepsilon$ is the relative permittivity of the dielectric, $\varepsilon_{0}$ is the permittivity of free space, $\mathbf{E}_{1}(\mathbf{r})$ is the electric field in region $1, \mathbf{E}_{2}(\mathbf{r})$ is the electric field in region 2.

\section{Results and Discussion}

The finite integration technique (FIT) and mode matching technique (MMT) were used to calculate the $Q$ factor caused by dielectric losses for different values of the air gap thickness in case of different $R / h$ ratios.

The dependences of the normalized quality factor $Q_{d} \tan \delta$ caused by dielectric losses of the $\mathrm{TM}_{010}$ mode in case $R_{S}=1,5 R$; $\tan \delta=10^{-3} ; \varepsilon=30$ versus normalized air gap thickness $d / h$ for various values of the $R / h$ ratio are presented in Fig. 2.

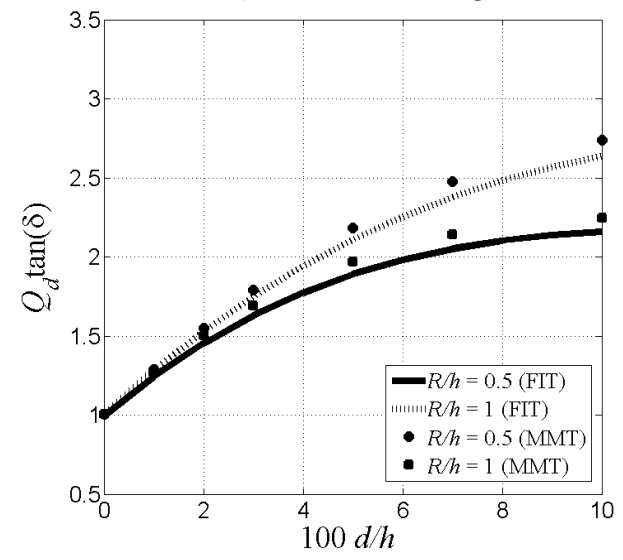

Fig. 2. Normalized $Q$ factor of the $T M_{010}$ mode caused by dielectric losses only versus normalized air gap thickness for tunable shielded cylindrical metaldielectric resonator with following parameters: $R_{S}=1,5 R ; \tan \delta=10^{-3} ; \varepsilon=30$.

It is clearly seen, that the $Q$ factor caused by dielectric loss increases as the air gap thickness increases. The principal reason of this behavior is redistribution of the electromagnetic energy from the dielectric cylinder to the air gap and thus the decreasing of the dielectric loss.
It is also demonstrated that the sensitivity of the $Q$ factor caused by dielectric loss to the air gap thickness increases in case of the $R / h$ ratio increase. The volume of the air gap increases with the $R / h$ ratio increase which results in more significant redistribution of the energy.

It should be noted that FIT and MMT results are in good agreement.

\section{Conclusion}

Investigation of the $Q$ factor of the tunable shielded cylindrical metal-dielectric resonator was performed. It was demonstrated that the $Q$ factor caused by dielectric loss increase in case of the air gap thickness increase.

The tunable shielded cylindrical metal-dielectric resonator maintains and even improves its $Q$ factor with the resonant frequency tuned. A composite shielded cylindrical metal-dielectric resonator with a constant air gap width can be used for high- $Q$ applications as well.

The sensitivity of the $Q$ factor caused by dielectric loss to the air gap thickness increases in case of $R / h$ ratio increases.

\section{References}

1. K. Savin, Yu. Prokopenko and G. A. E. Vandenbosch. (2013), "Mode Matching Technique Solution for Shielded Tunable Cylindrical Metal-Dielectric Resonator," 2013 IEEE XXXIII International Scientific Conference "Electronics and Nanotechnology" (ELNANO-2013), Kyiv, Ukraine, 16-19 April 2013, pp. 118-122.

2. F. Cheng, X. Lin, Y. Hu and Y. Fan. (2012), "Tunable Bandpass Filter using VaractorLoaded Quarter-Wavelength Resonator," 2012 International Conference on Microwave and Millimeter Wave Technology (ICMMT-2012), Shenzhen, China, 5-8 May 2012, vol. 5, DOI: 10.1109/ICMMT.2012.6230374.

3. N. Klein, G. Panaitov and K. S. Daya. (2004), "MEMS Tuneable Dielectric Resonator Structures for Microwave and Millimetre Wave Applications," The Fifth International Kharkov Symposium on Physics and Engineering of Microwave, Millimeter, and Submillimeter Waves, 2014 (MSMW-2004), Kharkov, Ukraine, 21-26 June 2004, vol. 1, pp. 35-39.

Поступила в редакцию 20 сентября 2014 г 
УДК 537.876 .42

К.Г. Савін, В.А. Казміренко, канд.техн.наук, Ю.В. Прокопенко, канд.техн.наук Національный технічний університет України «Київський політехнічний інститут», ул. Політехнічна 16, корпус 12, м. Київ, 03056, Україна.

\section{Добротність перелаштовуваного екранованого циліндричного метало-діелектричного резонатора, обумовлена діелектричними втратами}

Стаття присвячена дослідженню добротності перелаштовуваного екранованого цилиндричного метало-діелектричного резонатора, що обусловлена діелектричними втратами. Було показано, що діелектричні втрати спадають при перелаштуванні резонансної частоти шляхом утворення повітряної щілини. Розрахунки були проведені методом часткових областей та методом скінченних інтегралів. Результати розрахунків обома методами добре узгоджені. Бібл. 3 , рис. 2.

Ключові слова: метало-діелектричний резонатор, добротність, діелектричні втрати, повітряна щілина, перелаштування.

\section{УДК 537.876 .42}

К.Г. Савин, В.А. Казмиренко, канд.техн.наук, Ю.В. Прокопенко, канд.техн.наук Национальный технический университет Украины «Киевский политехнический институт», ул. Политехническая 16, корпус 12, г. Киев, 03056, Украина.

\section{Добротность перестраиваемого экранированного цилиндрическо- го металло-диэлектрического резонатора, обусловленная диэлектрическими потерями}

Статья посвящена исследованию добротности перестраиваемого экранированного цилиндрического металло-диэлектрического резонатора, обусловленной диэлектрическими потерями. Было показано, что диэлектрические потери падают при перестройке резонансной частоты путем внедрения воздушного зазора. Расчеты были проведены методом частичных областей и методом конечных интегралов. Результаты расчетов обоими методами хорошо согласуются. Библ. 3, рис. 2.

Ключевые слова: металло-диэлектрический резонатор, добротность, диэлектрические потери, воздушный зазор, перестройка.

\section{Список использованных источников}

1. K. Savin, Yu. Prokopenko and G. A. E. Vandenbosch. Mode Matching Technique Solution for Shielded Tunable Cylindrical Metal-Dielectric Resonator // 2013 IEEE XXXIII International Scientific Conference "Electronics and Nanotechnology" (ELNANO-2013). - Kyiv, Ukraine, 16-19 April 2013. pp. 118-122.

2. F. Cheng, X. Lin, Y. Hu and Y. Fan. Tunable Bandpass Filter using Varactor-Loaded QuarterWavelength Resonator // 2012 International Conference on Microwave and Millimeter Wave Technology (ICMMT-2012). - Shenzhen, China, 5-8 May 2012. - Vol. 5. - DOI: 10.1109/ICMMT.2012.6230374.

3. N. Klein, G. Panaitov and K. S. Daya. MEMS Tuneable Dielectric Resonator Structures for Microwave and Millimetre Wave Applications // The Fifth International Kharkov Symposium on Physics and Engineering of Microwave, Millimeter, and Submillimeter Waves (MSMW-2004). - Kharkov, Ukraine, 2126 June 2004. - Vol. 1. - pp. 35-39.

(c) Savin K., Kazmirenko V., Prokopenko Yu., 2014 